\title{
AKUMULASI VITAMIN C PADA OVARIUM IKAN NILA SAAT SIKLUS REPRODUKSI
}

\author{
Zafril Imran Azwar*)
}

\begin{abstract}
ABSTRAK
Suatu penelitian yang mempelajari akumulasi vitamin $C$ pada ovarium ikan nila saat siklus reproduksi telah dilakukan untuk mendapatkan informasi pola akumulasi dikaitkan dengan perkembangan ovarium. Sejumlah 120 ekor contoh ikan nila betina pada berbagai tingkat kematangan gonad ditangkap dari kolam pemeliharaan ikan. Kemudian ikan dimatikan dan ovarium diambil untuk mengetahui tingkat kematangan gonad (TKG), struktur oosit, serta kandungan vitamin $\mathrm{C}$ ovarium. Hasil pengamatan memperlihatkan bahwa kandungan vitamin $\mathrm{C}$ ikan nila pada tingkat kematangan gonad awal (TKG I) rata-rata $74,33 \mu \mathrm{g} / \mathrm{g}$ bobot basah kemudian meningkat dan mencapai kadar tertinggi pada TKG III rata-rata $155,98 \mu \mathrm{g} / \mathrm{g}$ bobot basah, dan kemudian menurun hingga TKG V. Persentase oosit stadium 3 (oosit vitelogenesis) tertinggi pada TKG III. Dengan demikian disimpulkan bahwa vitamin C berperan dalam proses pematangan ovarium ikan nila merah.
\end{abstract}

\section{ABSTRACT: Acumulation of vitamin $C$ in the ovarium of nile tilapia during reproductive cycle. By: Zafril Imran Azwar}

Acumulation of vitamin $C$ in the ovarium of red tilapia during reproductive cycle was investigated. One hundred twenty samples of females covering different stages of reproductive cycle were collected from fresh water ponds. The fishes were sacrifized and the ovarium were collected for analysis of gonad maturation stage (TKG), oocyt structure and vitamin C content in the ovarium. Results indicated that average of vitamin C content of ovarium at stage I was $74.33 \mathrm{ug} / \mathrm{g}$ (wet weight). The maximum content was found in stage III at level of $155.98 \mathrm{ug} / \mathrm{g}$ (wet weight), and afterwards in the next stage vitamin $C$ content decreased. The maximum of oocyt stadium 3 (oocyt vitelogenesis) was also found at this stage III. The findings indicate that vitamin C has a role in the reproductive cycle of red tilapia, and its content is related to ovarium development and oogenesis.

KEYWORDS: vitamin C, reproductive, nile tilapia

\section{PENDAHULUAN}

Informasi kebutuhan gizi induk ikan untuk kepentingan produksi benih masih sangat terbatas dan berbagai penelitian umumnya masih ditekankan hanya pada kebutuhan protein dan lemak, dan telah terbukti bahwa kecukupan protein dan lemak selama berlangsungnya siklus reproduksi sangat mempengaruhi perkembangan ovarium dan mutu telur. Informasi kebutuhan nutrea lainnya seperti vitamin pada saat siklus reproduksi masih sangat terbatas. Lutwak-Mann (1958) telah mengawali pendapat adanya ketergantungan fungsi gonad atas vitamin. Dia mencatat adanya fluktuasi asam askorbat (vitamin C) pada ovarium kelompok mamalia, namun belum dimengerti peranannya dalam fisiologis-reproduksi.

Ikan nila merah (Oreochromis sp.) adalah spesies ikan air tawar yang sudah populer dibudidayakan, disukai oleh masyarakat, mudah dibudidayakan pada beberapa ekosistem dan mempunyai peluang sebagai komoditas ekspor. Ikan ini mudah berbiak sepanjang tahun, dengan periode pemijahan yang berfluktuasi. Informasi mengenai kebutuhan gizi spesifik vitamin untuk pakan induk ikan nila belum banyak diketahui, namun diduga bahwa kesediaan vitamin pada ovarium sangat berperanan dalam siklus reproduksi. Berdasarkan permasalahan di atas dilakukan pengamatan akumulasi vitamin $\mathrm{C}$ pada ovarium ikan nila saat siklus reproduksi, sebagai informasi dasar kebutuhan dan peranan vitamin $\mathrm{C}$ dalam siklus reproduksi.

\section{BAHAN DAN METODE}

Contoh ikan nila yang digunakan dalam penelitian ini sebanyak 120 ekor yang diambil dari kolam pembesaran. Kisaran bobot ikan yang tertangkap adalah 68,72-168,93 g. Ikan dimatikan dan ovarium diambil. Sebagian ovarium disimpan dalam botol berisi formalin buffer fosfat untuk digunakan dalam pengamatan struktur oosit (distribusi ukuran) oosit dan pembuatan preparat histologis. Kemudian sebagian

-) Peneliti pada Balai Penelitian Perikanan Air Tawar Sukamandi 
contoh ovarium lainnya disimpan dalam kantong plastik, diisi dengan gas Nitrogen dan disimpan pada suhu $-30^{\circ} \mathrm{C}$ untuk analisis vitamin $\mathrm{C}$. Preparat histologi disiapkan dengan mengikuti prosedur yang dikemukakan oleh Chinabut, et al. (1991) dengan

\section{HASIL DAN BAHASAN}

Dari pengamatan terhadap 120 contoh induk ikan nila betina diperoleh data yang menggambarkan distribusi kandungan vitamin $\mathrm{C}$ ovarium pada berbagai

Table 1. Distribusi kandungan vitamin C ovarium pada setiap Tingkat Kematangan Gonad (TKG)

Table 1. Distribution of vitamin C content in ovarium at each gonad maturation stage (TKG)

\begin{tabular}{cccccc}
\hline \multirow{2}{*}{$\begin{array}{c}\text { Kandungan vitamin C } \\
\text { Vitamin C content }(\mu \mathrm{g} / \mathrm{g})\end{array}$} & \multicolumn{5}{c}{ Tingkat kematangan gonad (Gonad maturation stage) } \\
\cline { 2 - 6 } & $\mathrm{I}$ & II & III & IV & V \\
\hline $60-80$ & 8 & 0 & 0 & 0 & 0 \\
$81-100$ & 4 & 0 & 0 & 2 & 2 \\
$101-120$ & 0 & 10 & 6 & 11 & 6 \\
$121-140$ & 0 & 12 & 8 & 15 & 3 \\
$141-160$ & 0 & 5 & 11 & 6 & 0 \\
$161-180$ & 0 & 0 & 8 & 0 & 0 \\
$181-200$ & 0 & 0 & 3 & 0 & 0 \\
\hline Total & 12 & $\mathbf{2 7}$ & 35 & 34 & 12 \\
\hline
\end{tabular}

pewarnaan hematoksilin dan eosin. Preparat histologi dibuat untuk pengamatan diameter oosit pada setiap stadia perkembangan, dan melihat spesifik tingkat kematangan gonad (TKG). Struktur oosit diamati dengan menggunakan mikroskop binokuler yang dilengkapi mikrometer. Struktur oosit diklasifikasikan menurut stadium oosit (stadium awal, previtelogenesis, vitelogenesis, dan oosit matang) berdasarkan diameter oosit yang ditentukan dari pengamatan preparat histologis. Kandungan vitamin $\mathrm{C}$ ovarium dianalisis menurut metode pasangan ion (Schuep, et al., 1994) dengan menggunakan HPLC (High Performance Liquid Chromatography) pada panjang gelombang $254 \mathrm{~nm}$ dan coloumn stainles steel $(25 \times 40 \mathrm{~mm})$ dijenuhi oleh $\mathrm{C}_{18}$ diameter $5 \mu \mathrm{m}$ (Shadon Southern Products, Atmoor, UK). Fase mobil yang digunakan adalah bufer asetat $\mathrm{pH} 4.8$ dan vitamin C terelusi setelah 6-8 menit (Lampiran 1). Contoh ovarium sebanyak $0,1 \mathrm{~g}$ diekstraksi dengan $5 \mathrm{~mL}$ asam meta fosforik terdiri atas $0,2 \%$ ditiotreitol menggunakan penghancur jaringan (tissue homogenizer) dengan kecepatan 1.500 rpm selama 3 menit pada suhu $5^{\circ} \mathrm{C}$. Kemudian campuran dipusingkan dengan kecepatan 4.000 rpm selama 5 menit untuk memisahkan padatan dan larutan (filtrat). Filtrat disaring dengan menggunakan membran filter 0,45 $\mu \mathrm{m}$. Untuk mendapatkan informasi pola akumulasi kandungan vitamin C ovarium saat siklus reproduksi, data yang diperoleh disajikan dalam bentuk tabel frekuensi didasarkan pada tingkat kematangan gonad (TKG) contoh yang diamati. tingkat kematangan gonad (TKG) seperti tertera pada Tabel 1.

Kandungan vitamin $\mathrm{C}$ ovarium kelompok TKG I umumnya $(66,66 \%)$ berada pada kisaran $60-100 \mu \mathrm{g} / \mathrm{g}$ dan rata-rata $74,33 \mu \mathrm{g} / \mathrm{g}$, pada kelompok TKG II sebanyak $81,84 \%$ contoh berkisar $101-140 \mu \mathrm{g} / \mathrm{g}$ dan rata-rata $125.72 \mu \mathrm{g} / \mathrm{g}$, dari kelompok TKG III sebanyak $94,00 \%$ berkisar $101-180 \mu \mathrm{g} / \mathrm{g}$, dan rata-rata 155,98 $\mu \mathrm{g} / \mathrm{g}$, dari kelompok TKG IV sebanyak $94,00 \%$ berkisar 81-160 $\mu \mathrm{g} / \mathrm{g}$ dan rata-rata 127,57 $\mu \mathrm{g} / \mathrm{g}$, dan dari kelompok TKG V sebanyak $91,20 \%$ berkisar 81 $140 \mu \mathrm{g} / \mathrm{g}$ dengan rata-rata $112,00 \mu \mathrm{g} / \mathrm{g}$. Dari data pada Tabel 1 terlihat bahwa ada fluktuasi kadar vitamin C pada ovarium saat siklus reproduksi. Kandungan vitamin $C$ ovarium cenderung meningkat sejak awal dan mencapai maksimum pada TKG III, kemudian menurun sampai TKG V. Pola akumulasi vitamin C pada ovarium ikan nila saat siklus reproduksi sama dengan pola yang dijumpai pada spesies ikan trout (Onchorhyncus mykiss) (Sandnes, 1984), ikan Cod (Gadus morrua) (Sandnes \& Braekkan, 1981), dan ikan carp (Carassius carassius) (Saeymour, 1981). Dengan mengamati ovarium ikan trout tangkapan di alam, Sandnes (1984) mencatat bahwa kadar vitamin C ovarium pada musim reproduksi berkisar antara 143$379 \mu \mathrm{g} / \mathrm{g}$ dan kadar tertinggi pada masa "vitelogenesis". Sandnes \& Braekkan (1981) mencatat pula adanya kenaikan kadar vitamin $\mathrm{C}$ ovarium ikan cod dari 150 $\mu \mathrm{g} / \mathrm{g}$ pada awal menjadi $450 \mu \mathrm{g} / \mathrm{g}$ bobot ovarium basah pada saat perkembangan ovarium, kemudian menjelang pemijahan kandungan vitamin $\mathrm{C}$ menurun mencapai $100 \mu \mathrm{g} / \mathrm{g}$ bobot ovarium basah. 
Berdasarkan kandungan vitamin $\mathrm{C}$ ovarium dan tingkat kematangan gonad (TKG) ikan nila yang diamati terlihat bahwa terjadi perubahan kandungan vitamin $C$ ovarium sejalan dengan perkembangan oosit dalam ovarium. Sejak TKG I hingga TKG III kandungan vitamin C memperlihatkan pola meningkat. Pada TKG I seluruh oosit berada pada stadium 1 (awal), kemudian pada TKG II sebagian oosit berkembang mencapai oosit stadium 2 (stadium previtelogenesis) sebanyak $25,48 \%$ dan masih ditemui oosit stadium 1 sebanyak $74,52 \%$. Pada TKG III sebagian besar oosit ditemui pada stadium previtelogenesis sebanyak $35,41 \%$ dan stadium vitelogenesis sebanyak $33,46 \%$ dan pada TKG IV sebagian besar oosit terkelompok dalam dalam oosit stadium 4 (stadium matang) sebanyak $60,64 \%$. Sedangkan pada TKG V komposisi oosit pada ovarium di dominan oleh oosit stadium 1 dan 2 , sedikit ditemui oosit stadium 3 dan tidak detemui sama sekali oosit stadium 4 (Tabel 2). Terjadi perubahan struktur komposisi oosit pada ovarium ini sejalan dengan perubahan kandungan vitamin $C$ ovarium. Setelah TKG IV terlihat penurunan yang nyata kandungan vitamin $\mathrm{C}$ ovarium sejalan dengan meningkatnya komposisi oosit matang. Ini memperkuat dugaan bahwa pada fase tersebut terjadi penggunaan vitamin $\mathrm{C}$ ovarium yang cukup tinggi. Hasil penelitian Agrawal \& Mahajan (1980) pada ikan "India carp" (Labeo rohita, Catla catla, dan Cirrhina mrigala) yang tertangkap di alam mencatat bahwa kandungan vitamin C plasma darah meningkat pada masa perkembangan ovarium dan mencapai minimal pada masa setelah memijah. rendah dibandingkan dengan induk kontrol yang tidak disuntik. Kandungan vitamin $\mathrm{C}$ ovarium induk yang disuntik dengan hipofisis ikan mas adalah $65,9 \mu \mathrm{g} / \mathrm{g}$ induk kontrol mencapai $121,4 \mu \mathrm{g} / \mathrm{g}$, ukuran diameter oosit dari induk yang menerima perlakuan penyuntikan hipofisis adalah $958 \mu \mathrm{m}$, dan oosit induk kontrol adalah sebesar $899 \mu \mathrm{m}$. Percobaan Akiyama, et al. (1990) terhadap ikan sardin (Sardinops saxmelanostic) memperlihatkan bahwa ada penurunan vitamin $\mathrm{C}$ ovarium setelah ikan menerima suntikan LHRH. Percobaan Ishibashi, et al. (1994) pada ikan Oplegnatus fasciatus, spesies ikan yang memijah musiman menunjukkan bahwa tidak ditemui oosit yang mencapai stadium 3 pada ovarium induk yang diberi pakan tanpa suplementasi vitamin $\mathrm{C}$, sedangkan pada induk yang diberi pakan cukup vitamin $\mathrm{C}$ banyak ditemui oosit yang mencapai stadium 3 dan oosit stadium 4 (oosit matang) setelah induk dipelihara selama 8 bulan.

Djojosoebagio (1990) mengemukakan bahwa dalam biosintesis hormon steroid reproduksi terjadi beberapa tahapan reaksi hidroksilasi. Vitamin C berperanan dalam reaksi hidroksilasi biosintesis hormon steroid (Horning, et al., 1984). Pendapat ini didukung oleh hasil pengamatan Halver dalam Waagbo, et al., (1984) yang mencatat bahwa vitamin $\mathrm{C}$ diakumulasikan pada sel folikel yang mengitari sel telur. Pada jaringan ini terdapat sel teka yang berperanan dalam sintesis hormon steroid reproduksi (Zohar, 1991). Hasil penelitian Waagbo, et al., (1989) mencatat pula bahwa vitelogenin plasma dari induk ikan trout (Onchorhynchus mykiss) yang menerima

Tabel 2. Kisaran dan rata-rata kandungan vitamin C ( $\mu \mathrm{g} / \mathrm{g}$ bobot basah), dan distribusi oosit pada setiap tingkat kematangan gonad

Table 2. Range and average of vitamin C content in ovarium ( $\mathrm{\mu g} / \mathrm{g}$ wet weight) and distribution of oocyt (\%) at each gonad maturation stage

\begin{tabular}{ccccccc}
\hline \multirow{2}{*}{$\begin{array}{c}\text { Kematangan gonad } \\
\text { Maturation stages }\end{array}$} & $\begin{array}{c}\text { Kandungan vitamin C di ovarium } \\
\text { Vitamin C content of ovarium (ug/g) }\end{array}$ & \multicolumn{4}{c}{$\begin{array}{c}\text { Distribusi oosit } \\
\text { Distribution of oocyt }\end{array}$} \\
\cline { 2 - 7 } & Kisaran (Range) Rata-rata (Average) & $\mathbf{1}$ & $\mathbf{2}$ & $\mathbf{3}$ & $\mathbf{4}$ \\
\hline I & $60-100$ & 74.33 & 100.00 & 0.00 & 0.00 & 0.00 \\
II & $101-160$ & 125.72 & 74.52 & 25.48 & 0.00 & 0.00 \\
III & $101-200$ & 155.98 & 28.54 & 28.54 & 33.46 & 2.79 \\
IV & $81-160$ & 127.57 & 15.51 & 15.51 & 8.60 & 60.64 \\
V & $81-140$ & 108.25 & 45.66 & 45.66 & 6.68 & 0.00 \\
\hline
\end{tabular}

Adanya peranan vitamin $\mathrm{C}$ dalam perkembangan oosit diperlihatkan pula dari percobaan Saeymour (1981) yang memperlihatkan bahwa kandungan vitamin C ovarium induk ikan Carassius carassius setelah disuntik dengan kelenjar hipofisis ikan mas lebih pakan tanpa suplementasi vitamin C sangat rendah dibandingkan induk yang menerima pakan cukup vitamin C pada musim reproduksi. Dengan demikian ketersediaan vitamin C pada ovarium ikan nila berkaitan dengan proses vitelogenesis, karena pada 
fase ini terjadi proses akumulasi material telur yang menyebabkan perubahan ukuran dan stadium oosit.

Cardinal \& Underfriend dalam Soliman et al. (1986) mengemukakan pendapat lain bahwa tingginya kandungan vitamin C saat ovarium berkembang berkaitan dengan fungsinya sebagai kofaktor enzim prolin dan lisin hidroksilase yang mengkatalisis hidroksilasi dari prolin dan lisin, dan essensial untuk perkembangan normal jaringan kolagen. Pada penelitian ini tidak dilakukan evaluasi terhadap jaringan kolagen ovarium ikan nila. Namun menurut Sandnes et al. (1984), kolagen merupakan penyusun utama dinding dalam kantung ovarium. Halver dalam Waagbo et al. (1989) tidak mengamati adanya akumulasi vitamin $C$ di jaringan kolagen yang mengitari sel telur, sehingga disimpulkan pula bahwa pada saat ovarium berkembang vitamin $\mathrm{C}$ digunakan untuk sintesis kolagen.

Soliman et al. (1986) mengemukakan bahwa vitamin $\mathrm{C}$ dalam ransum yang diterima oleh induk dapat ditransfer ke telur, dan disiapkan untuk perkembangan embrio, serta sangat mempengaruhi kualitas telur. Pengamatannya pada ikan Oreochromis mossambicus dari induk yang diberi pakan tanpa vitamin C memperlihatkan bahwa kandungan vitamin C telurnya tidak terdeteksi, dan daya tetas telurnya lebih rendah dari telur yang diproduksi oleh induk yang menerima pakan cukup vitamin C. Sandnes (1984) telah mengamati kandungan vitamin $C$ telur dari 2 pembenihan ikan Salmon di Norwegia, pertama dari kelompok pembenihan yang memiliki derajat penetasan telur yang tinggi dan kedua kelompok yang selalu menghasilkan derajat penetasan telur yang rendah, dan diketahui bahwa kandungan vitamin C telur dari kelompok pertama adalah $65 \mu \mathrm{g} / \mathrm{g}$ dan dari kelompok kedua adalah $5 \mu \mathrm{g} / \mathrm{g}$. Pengamatan lanjut memperlihatkan bahwa induk yang menerima pakan dengan suplementasi vitamin C $1.000 \mathrm{mg} / \mathrm{kg}$ pakan, kandungan vitamin C telur mencapai $31 \mathrm{\mu g} / \mathrm{g}$ dan derajat penetasan telur $87 \%$, sedangkan telur dari induk yang menerima pakan tanpa vitamin C, kandungan vitamin C telur $5 \mu \mathrm{g} / \mathrm{g}$ dan derajat penetasan mencapai 25\%. Hasil penelitian Dabrowski \& Bloom (1994) mencatat bahwa 37\% cadangan vitamin C telur digunakan selama perkembangan embrio ikan trout. Ini memperlihatkan pula adanya peningkatan vitamin C ovarium pada masa siklus reproduksi berkaitan dengan akumulasi senyawa tersebut pada telur yang akan dimanfaatkan pada saat perkembangan embrio dan larva.

\section{KESIMPULAN DAN SARAN}

Berdasarkan hasil penelitian akumulasi vitamin C ovarium ikan nila saat siklus reproduksi dapat disimpulkan hal-hal sebagai berikut

1. Kandungan vitamin $\mathrm{C}$ ovarium berfluktuasi saat siklus reproduksi, dan mencapai maksimum pada TKG III, kemudian menurun hingga TKG $\mathrm{V}$. Peningkatan kandungan vitamin $\mathrm{C}$ ini berkaitan dengan peningkatan stadium oosit;

2 Vitamin C sangat dibutuhkan pada saat siklus reproduksi dan sebaiknya dijadikan salah satu aspek penting yang harus diperhatikan dalam formulasi pakan induk ikan nila.

\section{DAFTAR PUSTAKA}

Agrawal N. K., \& C. L. Mahajan. 1980. Comparative tissue ascorbic acid studies in fish. J. Fish. Biol., 17:135-141.

Akiyama, T., M. Shiraishi, T. Yamamoto, and K. Hirose. 1990. Variation of administered ascorbic acid levels during maturation and spawning periode in Sardine. Jap. Soc. of fisheries Meeting, October, Abs:436.

Chinabut, S., C. Limsuwan, and P. Kitsawat. 1991. Histology of the walking catfish, Clarias batrachus. IDRC. 93 pp.

Dabrowski, K. and J. H. Bloom. 1994. Ascorbic acid deposition in rainbowtrout (Oncorhynchus mykiss) eggs and survival of embryos. Comp. Biochem. Physiol. 109A(1):129-135.

Djojosoebagio, S. 1990. Fisiologi Kelenjar Endokrin II. PAU IPB dan Dept. P dan K. 253 pp.

Horning D.B., G.G. Glathaar, and U. Mosser. 1984. General aspect, of ascorbic acid function and metabolism. Proc. Ascorbic Acid in Domestic Animal. The Royal Danish Agricultural Soc. Copenhagen. p 3-24.

Ishibashi, Y., K. Kato, and S. Ikeda. 1994. Effect of dietary ascorbic acid supplementaqtion on gonadal maturation in Japanese parrot fish. Suisanzoshoku. 42 (2): 279-285

Lutwak-Mann, C. (1958). The dependence of gonadal function upon vitamin and other nutritional factors. Vitamin Hormon. 16:35-57.

Saeymour, E.A., 1981. Gonadal ascorbic acid and changes in lebel with ovarian development in the crussian carp (Carassius carassius). Comp. Bioche. Physiol. 70A:551-553.

Sandnes, K. 1981. Some aspects of ascorbic acid on reproduction in fish. Proc. Ascorbic Acid in Domestic Animals. The Royal Danish Agricultural Soc. Copenhagen. p:206-212.

Sandnes, K., Y. Ulgenes, O. R. Braekkan, and F. Utne. 1984. The effect of ascorbic acid supplementation in broodstock feed on reproduction of rainbowtrout (Oncorhynchus mykiss). Aquaculture. 43:167-177. 
Sandnes, K., and Braekkan. 1981. Ascorbic acid and reproductive cycle of ovaries in Cod (Gadus morrhua) Comp. Biochem. Physiol. 70:543-546.

Schuep, W., P. Hoffman, and E. Kock. 1994. The assay of ascorbic acid in tissue and the analysis of ascorbate-2-polyphosphate in feed and its stability. Roche Seminar, Jakarta. p:1-6.

Soliman, A. K., K. Jauncey, and R.J. Robert. 1986. The effect of dietary ascorbic acid supplementation on hatchability, survival rate and fry performance in Oreochromis mossambicus. Aquaculture. 59:197. 208.
Waagboo, R., T. Thorson, and K. Sandnes. 1989. Role of dietary ascorbic acid in vitelogenesis in rainbow trout. Aquaculture, 80:301-314.

Zohar, Y. 1991. Fish reproduction: Its physiology and artificial manipulation. In S. Shilo and S. Sarig (Eds.) Fish Culture in Warm Water Problems and Trends. GRC Press. p:65-119. 
Azwar Z.I.

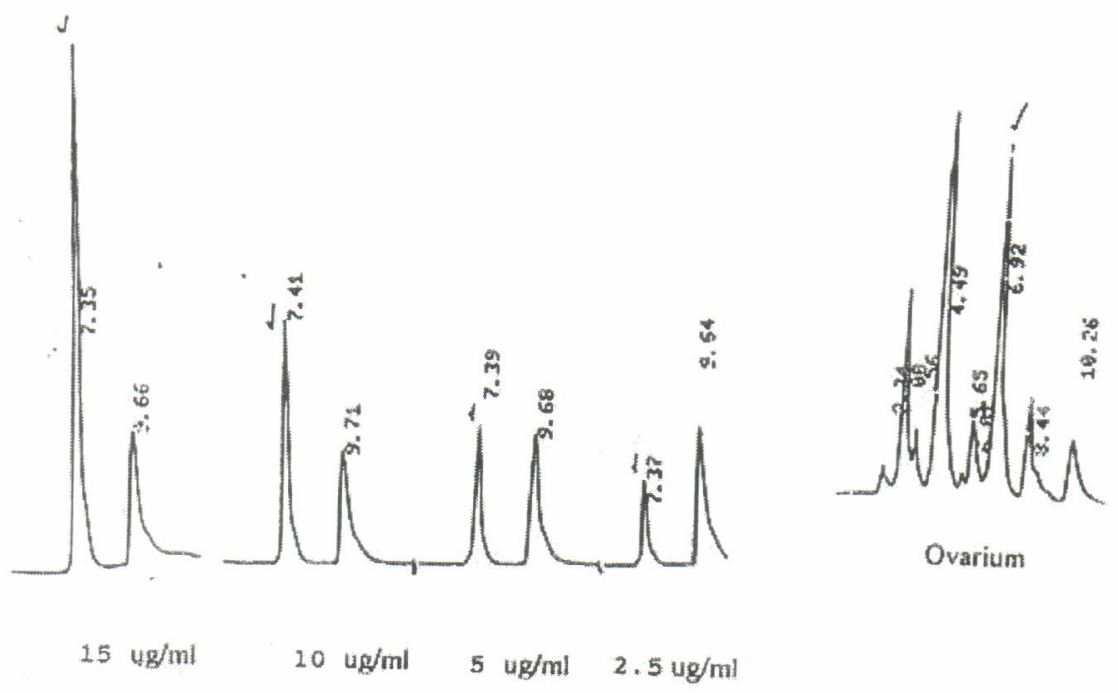

Lampiran 1. Kromatografi standar vitamin $\mathrm{C}$ dan vitamin $\mathrm{C}$ ovarium Annex 1. Chromatography of vitamin C standar and ovarium 